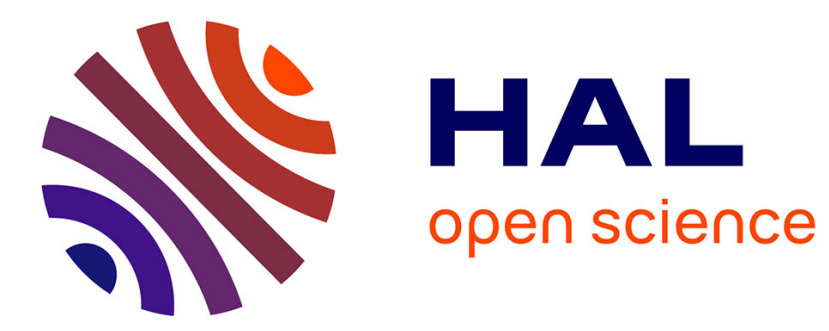

\title{
Mythological Crossings in Ancient Near East
}

\author{
Stéphanie Anthonioz
}

\section{To cite this version:}

Stéphanie Anthonioz. Mythological Crossings in Ancient Near East. Frontière×s : revue d'archéologie, histoire et histoire de l'art, 2019, 1, 10.35562/frontieres.124 . hal-02949658

\section{HAL Id: hal-02949658 \\ https://hal.science/hal-02949658}

Submitted on 29 Sep 2020

HAL is a multi-disciplinary open access archive for the deposit and dissemination of scientific research documents, whether they are published or not. The documents may come from teaching and research institutions in France or abroad, or from public or private research centers.
L'archive ouverte pluridisciplinaire HAL, est destinée au dépôt et à la diffusion de documents scientifiques de niveau recherche, publiés ou non, émanant des établissements d'enseignement et de recherche français ou étrangers, des laboratoires publics ou privés. 


\title{
Frontière's \\ Revue d'archéologie, histoire et histoire de l'art
}

\author{
Publiée avec le soutien de \\ la Maison de l'Orient et de la Méditerranée Jean Pouilloux \\ dans le cadre de la pépinière de revue de \\ l'Université JeAn MOULIN Lyon III
}

\section{$\mathbf{N}^{0} 1$ \\ Dépasser la frontière}

dir. Vincent CHOLLIER et Gaëlle PERROT 


\section{Frontière $\cdot s$}

Maison de l'Orient et de la Méditerranée

5/7 rue Raulin

69365 LYON CEDEX 07

frontiere-s@mom.fr

Pour soumettre un article et consulter l'appel en cours :

www.frontiere-s.mom.fr

https://publications-prairial.fr/frontiere-s

Directrice des publications

Françoise LE MORT, directrice de la MOM

Rédacteurs en chef

Fabien BIÈVRE-PERRIN (IRAA)

Vincent CHOLLIER (HiSoMA)

Gaëlle PERROT (HiSoMA)

\section{Comité de rédaction}

Loubna AYEB (Archéorient)

Mathilde DURIEZ (ArAr)

Cécile MOULIN (HiSoMA, ArAr)

\section{Secrétaire de rédaction}

Vincent CHOLLIER (HiSoMA)

\section{Direction du numéro}

Vincent CHOLLIER er Gaëlle PERROT (HiSoMA)

\section{Autrices}

Stéphanie ANTHONIOZ (Université catholique de Lille, Orient \& Méditerranée UMR 5167)

Marine LÉPÉE (Université Lumière Lyon 2, ArAr UMR 5138, Université de Lausanne, Institut d'Archéologie et des Sciences de l'Antiquité $\mathrm{CH}$ )

Élise PAMPANAY (Université Lumière Lyon 2, HiSoMA UMR 5189)

Nissaf SGHAÏER (Université Saint-Louis Bruxelles, Centre de recherches en histoire du droit, des institutions et de la société) Anne TICHIT (HALMA UMR 8164)

\section{Photo de couverture :}

Coupe de type A attique, Richmond (Virginia), Museum of Fine Arts, inv. 62.1.11, vers 520

Source : https://www.vmfa.museum/piction/6027262-182968811/ (CC-BY-NC) 


\section{Sommaire du numéro}

Mythological Crossings in Ancient Near East

Gilgameš and Ezekiel 47

Stéphanie Anthonioz

5

Les boutiques Dans Les COLONIES De Lyon et DE VIENNE ENTRE LE I ${ }^{\mathrm{ER}}$ S. AV. ET LE III ${ }^{\mathrm{E}}$ S. APR. J.-C. Franchir le seuil, dépasser la frontière

Marine Lépée

DiALOGUES D’ÉPOUX SUR LES STÈLES FUNÉRAIRES ATTIQUES

Dépasser la frontière de la mort

Élise Pampanay

LES VOYAGEURS OCCIDENTAUX À LA DÉCOUVERTE DE L'ALTÉRITÉ MUSUlMANE AU BAS MoYEN ÂGE L'exemple de Bertrandon de la Broquière

Nissaf Sghaïer

LE RENOUVELLEMENT DU RÉPERTOIRE ATTIQUE PAR EMPRUNTS

L'inspiration au-delà des frontières

Anne Tichit 



\title{
Mythological Crossings in Ancient Near East
}

\section{Gilgameš and Ezekiel 47}

DOI : $10.35562 /$ frontieres. 124

\section{Stéphanie Anthonioz}

Professeure, Université catholique de Lille, Orient \& Méditerranée (UMR 8167)

\begin{abstract}
The literary motif of crossing has been transmitted over generations in royal Mesopotamian inscriptions as well as in the Levant with its political and ideological issues, mostly royal conquest and victory. It also plays an important role in mythological sources particularly in the Epic of Gilgameš and also in the case of the divine vision in the book of Ezekiel which evidences different Mesopotamian influences. This contribution in its comparative approach adds to past research concerning echoes or dependence between the book of Ezekiel and Mesopotamian sources. It is also the occasion to reflect further on the use of motifs in ancient literature, the way they were transmitted and reinterpreted along particular lines of ideology or history. And finally, in deepening our understanding of the literary motif of crossing, it is highlighted how such a motif was indeed mythologically reworked to the point of mysticism: crossing the border of human reality and entering a fourth dimension beyond human grasp, divine and transcendent.
\end{abstract}

Keywords: crossing, literary motif, Epic of Gilgameš, Eze 47: I- I 2, heroic priority, divine transcendance

Résumé. Le motif littéraire que constitue la traversée s'est transmis de génération en génération dans les inscriptions royales mésopotamiennes comme au Levant, avec ses enjeux politiques et idéologiques que sont la conquête royale et la victoire. Or, ce motif littéraire est aussi présent dans les sources mythologiques, comme l'Épopée de Gilgameš, ou encore dans les sources bibliques avec la vision prophétique du livre d'Ezéchiel, célèbre pour ses influences mésopotamiennes. L'analyse de la relecture de ce motif, dans ces deux sources principalement, vise à enrichir le dossier comparatif les concernant. Il est aussi l'occasion d'étudier l'œuvre des scribes dans l'usage et la réinvention de motifs millénaires. En particulier, il démontre comment le motif de la traversée a été à un moment donné critiqué : cette critique a certes eu des retombées politiques mais aussi théologiques : l'échec de la traversée de Gilgameš et l'impossible traversée d'Ezéchiel deviennent les symptômes d'une frontière humaine au-delà de laquelle se situe le divin dans sa distance, voire sa transcendance.

Mots-clés : traversée, motif littéraire, Épopée de Gilgameš, Ez 47:I - I2, heroic priority, transcendance divine

Divine visions are rather rare in biblical texts, which might reflect the Deuteronomic prohibition of divine images. However, some prophetic visions do take place in a cultic setting, as for example in the books of Isaiah and Ezekiel, and show an anthropomorphic representation of the divinity, rather cosmic and royal in Isaiah, but fully human in Ezekiel (1:26). In these visions, animal creatures are also present, seraphîm in the case of Isaiah and keruvîm in the case of Ezekiel. These visions manifestly carry the reader into another world, crossing the borders of human reality. Stylistic and rhetorical devices are used to describe the divine and explore its transcendence. In this contribution, I would like to show how the literary motif of crossing, transmitted over generations in Mesopotamian royal inscriptions as well as in the Levant with its political and ideological issues - mostly royal conquest and victory - also plays an important role in mythological sources, particularly in the Epic of Gilgameš. Also, the divine vision in the book of Ezekiel evidences different Mesopotamian influences. Therefore, I propose to study the divine vision, identify and analyse the motif 
of crossing and replace it in the transmission of the motif in Mesopotamian sources. This contribution in its comparative approach adds to past research concerning echoes or dependence between the book of Ezekiel and Mesopotamian sources. ${ }^{1}$ It is also the occasion to reflect further on the use of motifs in ancient literature, the way they were transmitted and reinterpreted along particular lines of ideology or history. And finally, in deepening our understanding of the literary motif of crossing, it is highlighted how such a motif was indeed mythologically reworked to the point of mysticism: crossing the border of human reality and entering a fourth dimension beyond human grasp.

\section{The Continued Vision in the Book of Ezekiel: Exploration of Divine Frontiers and an Impossible Human Crossing}

The opening vision in the book of Ezekiel is methodically structured. The description consists of a theophany (1:4), followed by several elements: the four animals or living creatures (1:5-14), the wheel(s) $(1: 15-21)$, the firmament and the voice of the Almighty $(1: 22-25)$, the throne, the humanity and glory of the divinity (1:26-28). The revelation is graded, starting from natural elements such as the fire and ending in the divine humanity of Adam. From the biblical point of view, the vision is anchored in the Exodic divine manifestations that may be found in diverse episodes: the burning bush, the departure from Egypt, the crossing of the desert and the vision at Sinai. Some distance is, however, indicated from the beginning of the vision as only 'appearances' are envisioned. The use of the term 'appearance' ( $k e$ ' $y n$ ), constructed over the nominal root of the eye as the organ of sight, makes clear that what can be seen only imperfectly approaches the divine object in question. This is the beginning of what could be called a 'rhetoric of the vision,' what D.I. Block has called the 'language of analogy,' a description, not of the essence, but only of the aspect of the object seen. The rhetorical precautions are increased the more the divinity is approached and develops through the notions of resemblance (demût), ${ }^{3}$ aspect (mar'èh) ${ }^{4}$ which is a masculine substantive from the verbal root 'to see' and very close to the feminine substantive 'vision' (mar' $\hat{a})$. Certainly this last play on words is not by chance and reflects the tension created by this vision. Indeed, the vision-mar' $\hat{a}$ should reflect the object, whereas the aspect-mar'èh may only point to what can be seen. The distance between the object, what it is in essence and what can be seen of it, its appearance, becomes insurmountable.

In a similar way the living creatures, later identified with the keruvîm, are characterized in an anthropomorphic manner, ${ }^{5}$ and yet the presence of their wings and animal faces brings a distance in this humanity. Moreover, one is struck by the association of these creatures with the number four: four living creatures, four faces, four wings, four sides, four directions. The four with their fourfold elements are quoted four times $(1: 8.10 \times 3)$. This symbolism peculiar to the vision of Ezekiel is undeniably cosmic and universal as the four directions are evidently referred to. ${ }^{6}$ This however is common in Mesopotamian sources and has been studied for example in the divine portrait of the god Marduk. ${ }^{7}$ One could say, in the prophetic case, that the number four is also one of transcendence, as it allows here to enter into a fourth dimension that human intelligence cannot grasp. Indeed, the description is made in such a way that it is impossible for one's mind to represent it: how can one embrace the idea of four living creatures, having each four faces, and going each in the direction of its face? Is it not breaking the laws of space? The question of the genre may also be introduced here, ${ }^{8}$ as the living creatures are at times treated as grammatically feminine subjects and, at other times, as masculine (see verses 5-6, 9, 10, 12). This indecision concerning the genre of the creatures may be viewed as another device in describing the transcendence of the divine. The elements that have just been analysed should be envisioned, moreover, in their mobility and a movement of ascent. This characterizes the whole vision along

1 Aster 2015, p. 10-22; Petter 2011; Block 2001, p. 15-42; Kutsko 2000, p. 104; Bodi 1993, p.1-23; Bodi 1991.

2 Block 1988, p. 212. According to D.I. Block, the numerous textual difficulties should be considered as the consequence of the altered state of the prophetic mind: 'We all know from common experience that attempts to describe mental pictures while in a state of high excitement often comes out garbled with incomplete sentences, erratic grammar, confused vocabulary, and incoherent structure'. (p. 216). From our point of view, the textual difficulties are a matter of textual transmission, but also literary and ideological construction.

3 See Gen 1:26; 5:1, 3; 2 Ki 16:10; 2 Chr 4:3; Psa 58:5; Isa 13:4; 40:18; Ezek 1:5, 10, 13, 16, 22, 26, 28; 8:2; 10:1, 10, 21f; 23:15; Dan 10:16.

$4 \quad$ Gen $2: 9 ; 12: 11 ; 24: 16 ; 26: 7 ; 29: 17 ; 39: 6 ; 41: 2,21 ; 46: 2$; Exod 3:3; 24:17; 38:8; Lev 1:16; 13:3, 12, 20, 25, 30, 34, 43; 14:37; Num 8:4; 9:15; 12:6, 8; Deut 28:34, 67; Jos 22:10; Jdg 13:6; 1 Sam 3:15; 16:7; 17:42; 2 Sam 11:2; 14:27; 23:21; Est 1:11; 2:2f, 7; Job 4:16; 41:1; Eccl 6:9; 11:9; Cant 2:14; 5:15; Isa 11:3; 52:14; 53:2; Ezek 1:1, 5, 13, 16, 26; 8:2; 10:1, 9, 22; 11:24; 23:15; 40:2; 41:21; 42:11; 43:3; Dan 1:4, 13, 15; 8:15, 26; 9:23; 10:1, 6, 16, 18; Joel 2:4; Nah. 2:5.

5 See the references to the 'the resemblance of a man' (1:5), to 'human hands' $(1: 8)$ and to 'human face' $(1: 10)$.

6 Greenberg 2001, p. 60.

7 Kilmer 2007, p. 672-679; Honggeng 2001, p. 87-91

8 Block 1988, p. 201. 
with the circular movement of the wheels so that the divine system appears to be a complex and integrated one. ${ }^{9}$ The dimension we enter is truly cosmic and multidimensional, clearly impossible to grasp and represent for the human mind.

The vision continues in chapters 8-11 and later from chapter 40 on, on the mode of a visitation of the sanctuary that ends in the prophetic vision of the new Israel (40-48). On his visit, the prophet is systematically and divinely transported. In 43:5 and 44:4, the divine glory that had left the impious sanctuary in Jerusalem starts its return and fills the new holy place. In chapter 47 , the source of this sanctuary begins to flow renewing all of creation (47:1-12). ${ }^{10}$ This text should now be examined in more details, ${ }^{11}$ as it echoes numerous traditions and reinterprets in a particular way the motif of crossing:

Then he brought me back to the entrance of the temple; there, water was flowing from below the threshold of the temple toward the East (for the temple faced East); and the water was flowing down from below the south end of the threshold of the temple, south of the altar. ${ }^{2}$ Then he brought me out by way of the north gate, and led me around on the outside to the outer gate that faces toward the East; and the water was coming out on the south side. ${ }^{3}$ Going on eastward with a cord in his hand, the man measured one thousand cubits, and then had me cross the water; and it was ankle-deep. ${ }^{4}$ Again he measured one thousand, and had me cross the water; and it was knee-deep. Again he measured one thousand, and had me cross the water; and it was up to the waist. ${ }^{5}$ Again he measured one thousand, and it was a river that I could not cross, for the water had risen; it was deep enough to swim in, a river that could not be crossed. 'He said to me, 'Mortal, have you seen this?' Then he led me back along the bank of the river. ${ }^{7}$ As I came back, I saw on the bank of the river a great many trees (lit. a very great tree) on the one side and on the other. ${ }^{8} \mathrm{He}$ said to me, 'This water flows toward the eastern region and goes down into the Arabah; and when it enters the sea, the sea of stagnant waters, the water will become fresh. ${ }^{9}$ Wherever the double river goes, every living creature that swarms will live, and there will be very many fish, once these waters reach there. It will become fresh; and everything will live where the river goes. ${ }^{10} \mathrm{People}$ will stand fishing beside the sea from En-gedi to En-eglaim; it will be a place for the spreading of nets; its fish will be of a great many kinds, like the fish of the Great Sea. ${ }^{11}$ But its swamps and marshes will not become fresh; they are to be left for salt. ${ }^{12} \mathrm{On}$ the banks, on both sides of the river, there will grow all kinds of trees for food. Their leaves will not wither nor their fruit fail, but they will bear fresh fruit every month, because the water for them flows from the sanctuary. Their fruit will be for food, and their leaves for healing.' (Eze 47:1-12) ${ }^{12}$

Biblical references to the narratives of creation in the book of Genesis are evident and have been highlighted. The vocabulary of the living creatures (Gen 1:20.24.30; 2:19; 9:12.15; Eze 47:9) and the verb of swarming (Gen 1:20; 7:21; 8:17; 9:7; Eze 47:9) are indeed significant. ${ }^{13}$ But the image of the river also recalls the river flowing in Zion (Psa 46:4; Zech 13:1; 14:8; Joel 3:18). The reference in Zech 14:8 should be viewed in close dependence, because of the theme of the division of waters. ${ }^{14}$ The book of Revelation offers yet another important version, where the tree growing by the river is identified with the tree of life (Rev 22:1-2). In fact, the book of Revelation reads the Hebrew of Eze 47:7 carefully as it understands 'very great tree' ('és rav me'ôd) as a singular rather than a collective. This allows an easy identification with the tree of life which grows in Eden according to Gen 2:9. Certainly, this flowing of the waters retrospectively illuminates and explains the divine voice as the sound of many waters (Eze 1:24; 3:13; 10:5; 43:2). Eze 47:7 operates the temporal change from verbs in the perfect to imperfect and sanctions the entrance into an eschatological dimension. But this entrance is also the return toward the original time. Indeed, the waters flow towards the East, where Adam chased from Eden wandered from East to East. ${ }^{15}$ The return of the waters thus allows to understand the return of man in divine proximity and friendship. One may wonder, moreover, if the double

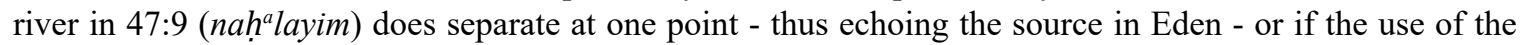
dual is metonymic: from one side to the other as verse 12 would intimate. Let us remember that in Gen 2:6 water flows to water the ground-'adamâ and the garden is next planted with the river dividing into four (Gen 2:10-14). Eden's hydrology is thus rich of a river dividing into four 'heads,' so as to water the earth.

9 Uehlinger 2015, p. 62-84; Uehlinger and Müller Trufaut 2001, p. 140-171.

10 For textual criticism see Barthélémy 1992, p. 409-415.

11 Bodi 2015, p. 22-37; Nocquet 2010, p. 331-343; Mulzer 2010, p. 403-418.

12 New Revised Standard Version (1987) with small corrections to keep close to the Hebrew Masoretic Text.

13 See Tuell 2000, p. 171-189.

14 Bodi 2015, p. 22-37; Terblanche 2004, p. 120-129.

15 Gen $2: 8,14 ; 3,24 ; 4,16 ; 11,2$. 
The symbolism of the four quarters is that of the representation of the world and more particularly the world seen by the Mesopotamian ideology, as the royal epithet recalls, šar kibrät erbetti, 'king of the four quarters/ regions. ${ }^{16}$ The biblical Eden becomes the place where ancient cosmology/mythology meets royal ideology. But only man (and not the monarch) is placed at the heart of creation in a kingly posture. ${ }^{17}$ What I wish to show now is how the fourfold crossing in Eze 47:3-5 - which as we have seen is an impossible crossing - is anchored, not only in the cosmology/ideology of the book of Genesis, but also in the tradition of the motif of crossing in Mesopotamian mythological texts, giving it a new ideological and mystical dimension, which has so far to my knowledge not been underlined.

\section{Ideology and Critique of the Motif of Crossing in MESOPOTAMIA}

Crossing is a recurring literary and iconographic motif in Mesopotamia. It suffices to read the royal Assyrian inscriptions from the second and first millennia BCE. Crossing belongs to what has been called 'heroic priority. ${ }^{18}$ From reign to reign, kings boast of greater high deeds than their predecessors, of having crossed farther and farther away, rivers and seas. This highly rhetorical device is not without strong anchorage into ancient cosmology and the representation of the world divided into four quarters and surrounded by water. It also recalls the royal epithet šar kibrät erbetti. Indeed, one could say that there is some kind of intimacy between the king and the divine. And this flirting could be precisely the object of the denunciation of the royal state in the Epic of Gilgameš. The hero is certainly presented in the first tablet by a series of royal epithets that manifest his royal and divine mediation:

37. Gilgameš so tall, perfect and terrible,

38. who opened passes in the mountains (pētû nērebēti ša huršāni);

39. who dug wells on the hill-flanks,

40. and crossed the ocean, the wide sea (ēbir tâmti tâmti rapašti), as far as the sunrise (ana șìt

šamši);

41. who scoured the world-regions ever searching for life (hā'it kibrāti mušste' $\hat{u}$ balāti),

42. and reached by his strength Utta-napišti the Far-Away;

43. who restored the cult-centers that the Deluge destroyed,

44. and established the proper rites for the human race!

45. Who is there that can be compared with him in kingly status,

46. and can say like Gilgameš, 'It is I am the king'?'19

Gilgameš is êbir tâmti tâmti rapašti ana șit šamši, the one who crossed the ocean, the wide sea as far as the sunrise. The discovery of the fragment from Ugarit (RS 94.2066) not only confirms the epithet but gives it all primacy, as it comes first among all others. ${ }^{20}$ The royal crossing is thus one of Gilgameš's greatest high deed. It strikingly echoes Sargon II when he claims in his inscriptions to have opened ways in faraway mountains, accessed impenetrable places (huršanī bìrūti ša nērebšunu ašț la mīna iptuma, 1.5), seen the farthest regions (ēmuru durugšun, 1.5), and crossed again and again (ètebbiru nagab mițāti, 1.6). ${ }^{21}$ Does he not resemble the hero of the epic and the ideal of kingship when he opens ways in the mountains (pētû nērebēti

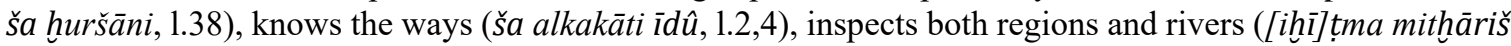
[kibrāti], 1.5), and above all crosses (ēbir, 1.9,40)? If contacts between the two literary pieces appear numerous, the nagbu connection is indeed interesting. The expression nagab mitrāti (1.6) may be simply translated waters from the canals. However, the semantics of nagbu is much deeper, as it can refer to a source and a fountain as well as the vast body of underground waters of which Ea is the master. It also designates totality in poetic texts. Indeed, in the beginning of the Epic, Gilgameš is the one who has seen nagba. This epithet

16 According to the Chicago Assyrian Dictionary, kibrätu, in the plural, refers to 'regions' (in connection with the four regions of the inhabited world), 'edge,' 'shoreline.' Note that the substantive kibru, in the sing. designates the 'bank' (of a canal, a river), 'seashore.'

17 Schüle 2005, p. 1-19; Dick 1998, p. 111-116; Parpola 1993, p. 161-208.

18 Anthonioz 2013, p. 85-99; Tadmor 1999, p. 55-62; Liverani 1979, p. 305-314.

19 George 2003, p. 540-541.

20 "1. [Lui qui a tout vu, (lui,)] le fondement de la terre, 2. Qui a connu les chemins, tous, (lui) qui était sage, 3. [Gilgameš, qui] a tout vu, (lui,) le fondement de la terre, 4. Qui a connu les chemins, tous, (lui) qui était sage, 5. Il inspecta également les régions/rives. 6. Il saisit la totalité de la sagesse de toute chose, 7. Il a vu le secret, il a ouvert ce qui était recouvert. (Ugarit version only 8. C'est lui qui a pris le chemin lointain d'Uturnapušti, 9. Il a traversé la mer, la vaste mer, vers le soleil levant. (ébir tâmtam tâmtam rapašta adi șîti šamši ) 8/10. Il a rapporté le récit de ce qui s'est passé avant le déluge.” Arnaud 2007, p. 130-133.

21 For example, Room II, ii, Palace of Khorsabad, see A. Fuchs 1994. 
is twice repeated (̌̌a nagba immuru, 1.1,3). If nagbu is connected to the crossing of Gilgameš who must cross the waters of death before he can cross the waters of life, ${ }^{22}$ then Sargon's crossing has to do with the ideal of kingship. However, it is not certain that the mythological discourse so exalts royal crossings. After all, does not it end in a failure and has not the alewife warned Gilgameš against any possibility of crossing in the tenth tablet?

72. Gilgameš spoke to her, to the ale-wife:

73. 'Now ale-wife, what is the road to Üta-napištim?

74. What is its landmark? Give it to me!

75. Do give me its landmark!

76. If it may be done, I will cross the ocean (šumma naț̂ma tâmta lübir)!

77. if it may not be done, I will roam the wild!

78. The ale-wife spoke to him, to Gilgameš:

79. "There never was, O Gilgameš, a way across (ul ibši ${ }^{d}$ gilgameš nēberu matīma),

80. and since the days of old none who can cross the ocean (u mamma ša ultu ūm șât mātim la ibbiru tâmta).

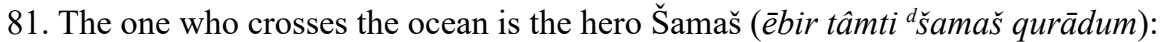

82. apart from Šamaš, who is there that can cross the ocean (akla '̌́amaš ibbir mannu)?

83. The crossing is perilous, its way full of hazard (pašqat nēbertum šupšuqat uruhša),

84. and in between are the Waters of Death, that lie across the passage forward.

85. So besides, Gilgameš, (once) you have crossed the ocean,

86. when you reach the Waters of Death, what will you do?

87. O Gilgameš, there is Ur-šanabi, the boatman of Üta-napišti,

88. and the Stone Ones are with him as he strips a cedar in the midst of the forest.

89. Go then, and let him see your face!

90. if [it may be] done, cross with him (šumma națuma ebir ittišu)

91. if it may not be done, turn around (and go) back (šumma la națûma ihis arkika)!"23

The same lexical field of ways or passages may be underlined (nèrebu), but this time the ale-wife insists that no crossing is possible (ul ibši ${ }^{d}$ gilgameš nēberu matīma, 1.83), because crossing is the very prerogative of the divinity Šamaš: ēbir tâmti ${ }^{d}$ Šamaš qurādum akla ď̃amaš ibbir mannu (1.85), so that the connection with the famous hymn to Šamaš as the only one ever crossing time and again the wide sea is now evident (tetenībir tamâtum rapaštum šadilta). ${ }^{24}$ The sun in its daily crossing embraces seas and cosmic borders, countries and peoples, and knows every heart and deed, pursuing every creature in justice and mercy. The sun as the divinity of justice is the only one to cross the world. One should insist on the fact that Gilgameš crossing is that of the sea and thus is also not without connection to Marduk's crossing in Enûma eliš, as the one who keeps crossing the sea (ša qerbiš tiamat ìtebbiru VII 128/ša tiāmat rapašta ìtibbiru VII 74). It is not about any crossing but clearly a divine crossing that of Šamaš and that of Marduk.

However, after having said that no crossing was possible, except that of Šamaš, Šiduri the ale-wife describes the crossing in terms familiar to the royal inscriptions: pašqu, perilous and šupšuqu, full of hazard (intensive of the same root: lit. very narrow and perilous). Finally, Gilgameš is allowed to cross with the šût abni (the Stone Ones). ${ }^{25}$ They make the crossing possible, the crossing of the waters of death. But as Gilgameš meets the hero of the Flood Utta-napišti, from whom he receives the plant of life, alas, it is in the end stolen from him. So the hero has to go back home in Uruk empty-handed. Without the life eternal he was looking after, he shall die just like his friend Enkidu. It is clear that behind his disillusion lies a critique of the royal discourse and propaganda. Is not the king flirting with the divine as he assumes crossing again and again over countries and waters? Does he not make himself the equal of the gods Šamaš/Marduk? Certainly the mythological discourse is also a reflection upon the nature of political power and the representation of the king. ${ }^{26}$ In regard to this analysis, the motif of crossing in the Epic of Gilgameš finds a precise function that is not so much the official discourse found in the royal inscriptions but, on the contrary, a critique of it, a counter-propaganda that aims at a relative royal glorification not an absolute one, at the right definition of mediation. This analysis is all the more interesting if one remembers the concept of heroic priority leading especially the Sar-

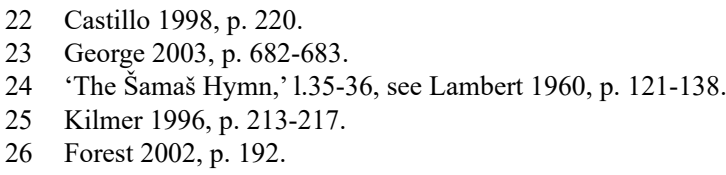


gonids to cross frontiers even to the end of the cosmos. H. Tadmor had indeed remarked how the sovereigns in the period made use of divine epithets and attributes to their own profit. ${ }^{27}$

If we accept the critique that constitutes the Epic on a political and theological level, clearly the motif of crossing is pivotal: the very motif that connotes heroic priority is the one to mark the limits and frontiers that Gilgameš as king should not cross. In light of this, it becomes possible to clarify the cosmology and ideology of the new creation in Eze 47. If there are not four rivers (cf Gen 2:10-14), nor four quarters, there are four crossings of which the last is an impossible one. If one considers the usual symbolism of universalism of number four in the sources analysed, this impossible crossing takes on a new meaning, beyond that of universalism, and coherent with the continued divine vision in the book of Ezekiel, that is a fourth dimension that cannot be crossed, a divine realm from which human being, be he king, is not allowed to enter, a divine realm that may not be crossed. The motif in its biblical reinterpretation acquires a new significance, a mystical one: just as there is a divine dimension in the prophetic vision that hinders from getting to and knowing the object seen, so there is a divine dimension in the new creation of the book of Ezekiel, one that cannot be grasped, that must remain beyond human limits and borders, touching upon divine transcendence. In both sources, the Epic of Gilgameš and Eze 47:1-12, though in different manners, in a cosmological and royal manner in the former, in a metaphysical manner in the latter, it appears that the motif of crossing is reinvested to mark the limits of human knowledge and endeavours. The failure of Gilgameš crossing just as the impossible crossing of the prophet in Eze 47 not only mark human limits, physical/cosmological or metaphysical, but signal the borders and frontiers beyond which one may not cross: beyond is the unapproachable, divine and, for the prophetic mind, beyond is the transcendent.

27 'In these eloquently exaggerated records of royal self-praise, the protagonist is naturally the ever-victorious king. Yet the role of the gods there is not a mere figure of speech. Wars were always sanctioned by gods. It is mostly Ashur's "trust-inspiring oracle" (takul$t u$ ), his glory, or his mighty weapons in the king's hands that bring about the victory. It was only later, in the eighth and seventh centuries, that kings usurped the divine epithets, attributing to themselves the terror-inspiring radiance (puluhtu) that overwhelms the enemy.' Tadmor 1975, p. 36. 


\section{BIBLIOGRAPHY}

Aster S.Z. 2015, « Ezekiel's Adaptation of Mesopotamian Melammu », Welt des Orients 45, p. 10-22.

Anthonioz S. 2013, « Les îles ou les extrémités du monde connu : regards assyriens et bibliques », Acta orientalia belgica 26, p. 85-99.

Arnaud D. 2007, Corpus des textes de bibliothèque de Ras Shamra-Ougarit (1936-2000) en sumérien, babylonien et assyrien, Aula OrientalisSupplementa 23, Barcelone.

BARTHÉLÉMY D. 1992, Critique textuelle de l'Ancien Testament. Tome 3. Ézéchiel, Daniel et les 12 prophètes, Orbis Biblicus et Orientalis 50/3, Fribourg-Göttingen, p. 409-415.

BLOCK D.I. 2001, « Divine Abandonment: Ezekiel’s Adaptation of an Ancient Near Eastern Motif », in M.S. Odell et J.T. Strong (éd.), The Book of Ezekiel, SBL SS 9, Atlanta, p. 15-42.

- 1988, « Text and Emotion: A Study in the 'Corruptions' in Ezekiel's Inaugural Vision (Ezekiel 1:4-28) », Catholic Biblical Quarterly 50, p. $418-442$.

BoDi D. 2015, « The Double Current and the Tree of Healing in Ezekiel 47:1-12 in Light of Babylonian Iconography and Texts », Die Welt des Orients 45, p. 22-37.

— 1993, « Le livre d'Ézéchiel et le poème d'Erra », Études théologiques et religieuses 68, p. 1-23.

- 1991, The Book of Ezekiel and the Poem of Erra, Orbis Biblicus et Orientalis 104, FribourgGöttingen.

Castillo J.S. 1998, « Nagbu: Totality or Abyss in the First Verse of Gilgamesh », Iraq 60, p. 219-221.

Dick M.B. 1998, « The Relationship Between the Cult Image and the Deity in Mesopotamia », in J. Prosecky (éd.), Intellectual Life in the Ancient Near East, Prague, p. 111-116.
FOREST J.-D. 2002, L'épopée de Gilgamesh et sa postérité : introduction au langage symbolique, Paris.

FuCHS A. 1994: Die Inschriften Sargons II aus Khorsabad, Göttingen.

George A.R. 2003, The Babylonian Gilgamesh Epic: Introduction, Critical Edition and Cuneiform Texts, Oxford.

GreenberG M. 2001, Ezechiel 1-20, Herders theologischer Kommentar zum Alten Testament, Fribourg-en-Brisgau.

Honggeng G. 2001, « The Mysterious FourFaces Statue (OIM A719) », Journal of Ancient Civilizations 16, p. 87-91.

KILMER A.D. 2007, " The Horses and Other Features of Marduk's Attack Chariot (EE IV) and Comparanda », Journal for Semitics 16, p. 672-679.

— 1996, « Crossing the Waters of Death: The Stone Things in the Gilgamesh Epic », Wiener Zeitschrift für die Kunde des Morgenlandes 86, p. 213-217.

Kutsko J.F. 2000, Between Heaven and Earth: Divine Presence and Absence in the Book of Ezekiel, Winona Lake.

LAMBERT W.G. 1960, Babylonian Wisdom Literature, Oxford.

LiVERANi M. 1979, « The Ideology of the Assyrian Empire », in M. Trolle Larsen (éd.), Power and Propaganda. A Symposium on Ancient Empires, Copenhague, p. 305-314.

Nocquet D. 2010, « Ez 47,1-12 et le jaillissement de l'eau à la fin des temps : vers une nouvelle Égypte ? », in J. Vermeylen (éd.), Les prophètes de la Bible et la fin des temps, Paris, p. 331-343.

Mulzer M. 2010, « Wasser vom Tempel (Ez 47,1-12) », in S. Ernst et M. Häusl (éd.), Kulte, Priester, Rituale: Beiträge zu Kult und Kultkritik im Alten Testament und Alten Orient: Festschrift für Theodor Seidl zum 65. Geburtstag, St. Ottilien, p. 403-418.

PARPola S. 1993, « The Assyrian Tree of Life: Tracing the Origins of Jewish Monotheism and 
Greek Philosophy ", Journal of Near Eastern Studies 52, p. 161-208.

PetTer D.L. 2011, The Book of Ezekiel and Mesopotamian City Laments, Orbis Biblicus et Orientalis 246, Fribourg-Göttingen.

Schüle A. 2005, « Made in the Image of God: The Concepts of Divine Images in Gen 1-3 », Zeitschrift für die alttestamentliche Wissenschaft 117, p. 1-19.

TADMOR H. 1999, « World Dominion: The Expanding Horizon of the Assyrian Empire », in L. Milano, S. De Martino et F. Fales (éd.), Landscapes: Territories, Frontiers and Horizons in the Ancient Near East, Papers Presented to the $44^{\text {th }}$ Rencontre Assyriologique Internationale, Venezia 7-11 July 1997, Padova, p. 55- 62.

- 1975, « Assyria and the West: The Ninth Century and Its Aftermath », in J.J.M. Roberts et
H. Goedicke (éd.), Unity and Diversity, Baltimore, p. 36-48.

Terblanche M.D. 2004, « An Abundance of Living Waters: The Intertextual Relationship between Zechariah 14:8 and Ezekiel 47:1-12 », Old Testament Essays 17, p. 120-129.

Tuell S.S. 2000, « The Rivers of Paradise: Ezekiel 47:1-12 and Genesis 2:10-14 », in T.W. Sibley (éd.), God Who Creates, Grand Rapids, p. 171-189.

Uehlinger C. 2015, «Virtual Vision vs. Actual Show: Strategies of Visualization in the Book of Ezekiel », Die Welt des Orients 45, p. 62-84.

UeHLINGER C. et Müller Trufaut S. 2001, «Ezekiel 1, Babylonian Cosmological Scholarship and Iconography: Attempts at Further Refinement », Theologische Zeitschrift 57, p. 140-171. 